\title{
Assessing Potential of Rainwater Harvesting: Case Study Building in Bangkok
}

\author{
Paron Monjaiang, Nantamol Limphitakphong, Premrudee Kanchanapiya, Thanapol Tantisattayakul, \\ and Orathai Chavalparit
}

\begin{abstract}
This study was aimed to make an assessment for the potential of rainwater harvesting system in Thailand. Both hydrological performance and economic feasibility were used to develop the RWH model for Bangkok, the capital city of Thailand. Net present value (NPV) was applied to analyze the cost effectiveness of rainwater harvesting system. To be summarized, the rainwater harvesting can potentially save tap water consumption in buildings which also gain financial profit depending on the designated system. In this case study, the installation of the RWH system with rainwater tank with the capacity of $30 \mathrm{~m}^{3}$ was suggested due to the ability to save approximately $\$ 13,370$ with the payback period of 34.8 years. In addition, this method can also the demand of tap water resource for $46,509 \mathrm{~m}^{3}$. For the buildings with higher tap water demand or higher tap water tariff, installing rainwater harvesting system would be strongly recommended for the implementation of rainwater harvesting system. In order to enhance the water resource management towards sustainability, rainwater harvesting system should be considered for the building design later on.
\end{abstract}

Index Terms-Green infrastructure, rainwater harvesting, sustainable water resource management.

\section{INTRODUCTION}

Sustainable development is a broad concept that places emphasis on today's livelihoods which affected the well-being of humanity in the future. Due to the current economic, social and environmental situations, the concept of sustainable development has still received unprecedented attention. However, one of the concept that is gaining attention for moving towards the sustainability goals is "Green infrastructure". The "Green infrastructure" has the implications for utilizing natural methods in urban development in order to achieve the environmental and sustainable development goals. The examples are green roof

Manuscript received January 11, 2018; revised July 2, 2018. This research was funded by the Ratchadapisek Sompoch Endowment Fund (2016), Chulalongkorn University (CU-59-002-IC)

Paron Monjaiang and Orathai Chavalparit are with the Department of Environmental Engineering, Chulalongkorn University, Bangkok, 10330, Thailand (Corresponding author: Orathai Chavalparit; e-mail: jayparon@gmail.com, orathai.c@chula.ac.th).

Nantamol Limphitakphong is with the Research Unit of Environmental Management and Sustainable Industry, Chulalongkorn University, Bangkok, 10330, Thailand (e-mail: nantamoll@gmail.com).

Premrudee Kanchanapiya is with the National Metal and Materials Technology Center, 114 Thailand Science Park, Pathumthani, 12120, Thailand (e-mail: premrudk@gmail.com).

Thanapol Tantisattayakul is with the Faculty of Science and Technology, Thammasat University Rangsit Campus, Pathumthani, 12121, Thailand (e-mail: thanapolosk@hotmail.com).
[1]-[3], permeable pavement [4]-[6], and rainwater harvesting [7]-[9].

Rainwater harvesting (RWH) is one of "Green infrastructure" technique that involving the design for the collection and storage of rainwater runoff from building roof as a non-potable source within domestic, commercial, institutional and drinking water industrial sectors. With the increasing demand in the water resource globally due to the extensively exploited of the water resource, this technique can be a promising alternative for water supply as well as for the improvement of storm water drainage systems. There are numerous practices of RWH around the world either by developed or developing countries. United States, Germany, Spain and Australia have implemented rainwater harvesting policies at different governmental levels which addition of economic incentives [10]-[13]. In Thailand, this technique has been taking a deep root for more than a century mostly in the rural area. For the urban area, this approach is not frequently applied due to a strong concern on air pollution which affecting the quality of rainwater in the city as compared to rural area. Rainwater harvesting system, however, is more economically feasible in higher water demand areas [14]. This study, therefore, aimed to make the assessment for the potential of rainwater harvesting in Bangkok, the capital city of Thailand by using the study building where the amount of water demand is high as a case study. Both the quantity of tap water reduction and economic feasibility from rainwater harvesting system were evaluated. As a result, the sustainable water resource management could help alleviate the problem of flooding which occurred more frequently during the rainy season and drought in the summer in Thailand.

\section{METHODOLOGY}

For the concept of rainwater harvesting, the rain falling on the roof is collected and passed through the filter system and stored in the rainwater tank. The collected water can be used for the replacement of the tap water utilization as shown in Fig 1. The model calculation for the amount of available rainwater in RWH system is demonstrated in Fig 2. Data input in this model also including the rainfall volume, roof area, rainwater collection tank capacity and water consumption rate for the building.

Rainfall volume; $\mathrm{R}\left(\mathrm{m}^{3} /\right.$ day) can be calculated by using rainfall data; $\mathrm{H}(\mathrm{mm})$ for every 3 hours a day; " $\mathrm{n}$ " during the year of 2015 - 2016 was gathered from Department of Meteorology and the roof area of the case study building; A $\left(\mathrm{m}^{2}\right)$ as Eq. 1 


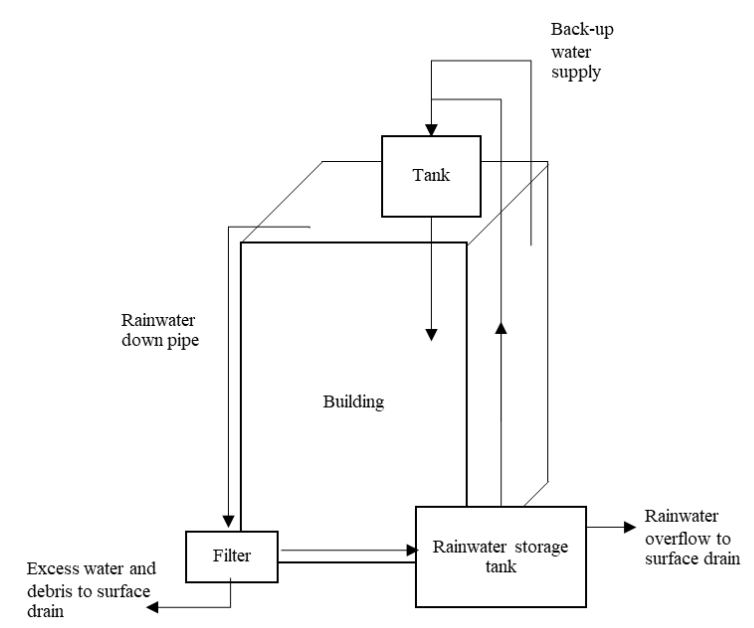

Fig. 1. Components of rainwater harvesting system.

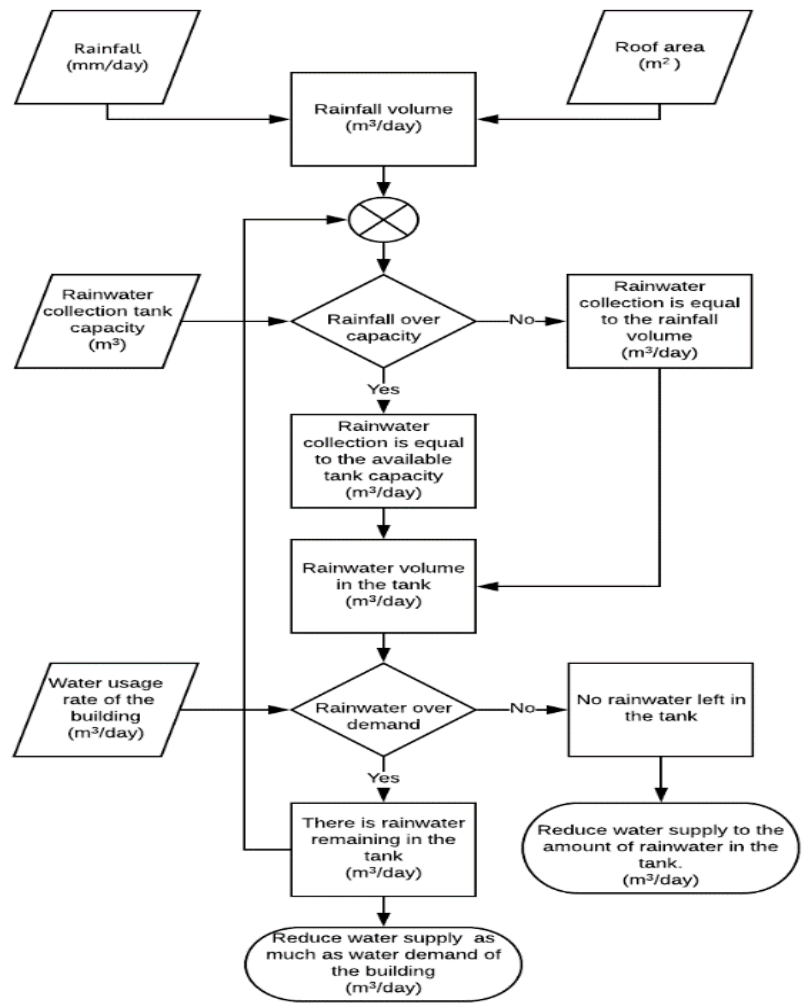

Fig. 2. Calculation model of RWH in Bangkok building case study.

$$
\mathrm{R}_{\mathrm{n}}=\frac{\mathrm{H}_{\mathrm{n}} \times \mathrm{A}}{1,000}
$$

Rainwater collection tanks capacity is varied in order to differentiate the output of the rainwater tanks at different capacities. The results can be used for the decision making for the optimum capacity selection later on. The data of water consumption rate for the building $\left(\mathrm{m}^{3} /\right.$ day) can be derived from dividing the monthly water consumption statistics of the building by the number of days a month.

On the daily basis, the amount of rainfall and the roof area were put in to an estimation for the volume of rainwater. If rainfall volume is more than rainwater collection tank capacity, the rainwater collection is equal to the available tank capacity. Otherwise, the rainwater collection is equal to the rainfall volume. Then, compare the rainwater in the tank with the water consumption rate of the building. If rainwater over the demand, then there is a rainwater remaining in the tank and the tap water reduction was equal to the tap water demand of the building. Otherwise, the tap water reduction was equal to the amount of rainwater in the tank.

The 100-year Engineering building of Chulalongkorn University which located in the heart of Bangkok was used as a case study building. Net present value (NPV) was also applied to analyze the cost effectiveness of the RWH system.

\section{RESULTS AND DISCUSSIONS}

The rainfall data and water demand of the building as shown in Fig 3 emphasized that during the summer period, the rainfall was not enough to meet the water demand of the building, whilst during the rainy season there was enough rainwater left to be reserved for utilization during summer if there is sufficient rain water tank capacity. By applying the rainfall data (Fig 3) into the rainwater process flow diagram (Fig 2), it can be stated that the RWH system allows the rainwater to be used for the replacement of the tap water consumption in the building as illustrated in Fig 4. The $10 \mathrm{~m}^{3}$ rainwater tank could reduce the tap water demand for 30,000 $\mathrm{m}^{3}$, while $60,000 \mathrm{~m}^{3}$ could potentially be saved via using a tank which has the capacity over $80 \mathrm{~m}^{3}$. In the first stage, the tank with the capacity between $10-40 \mathrm{~m}^{3}$ could not reserve the rainwater for the tab water replacement during the rain insufficient period due to its small capacity. While the rainwater tank with the capacity over $50 \mathrm{~m}^{3}$ showed no significantly difference on the amount of tap water reduction due to its sufficient capacity to supply the water even on the day that has no rainfall for several consecutive days.

Among 6 levels of rainfall distribution as shown in Fig. 5, the highest frequency of $80 \%$ was found at level 1, rainfall intensity is not exceeded $4 \mathrm{~mm} / \mathrm{h}$. This intensity, therefore, was used to design a water filtration system in relation to the roof area of the building and the capacity of the rainwater tank. Based on available commercial filter in Thailand, four filters with the filtration rate of $1-1.5 \mathrm{~m}^{3} / \mathrm{h}$ are required for all size of tank capacity except the smallest one which can be installed for only three systems.

In order to evaluate the cost effectiveness of RWH system, the cost of RWH installation involving the rainwater tank and filtration system were examined versus the price of saving tap water reduction as demonstrated in Fig 6. In addition, all three parameters regarding cost effectiveness were calculated based on the NPV analysis in unit of USD (\$) with the assumption discount rate of $2 \%$. The project's lifetime was assumed to be 40 years. For further explanation, assume that throughout a service life of rainwater harvesting the installation cost for rainwater tank with capacity of $10 \mathrm{~m}^{3}$ is $\$ 5,640$ ( $\$ 2018$ for rainwater tank cost plus $\$ 3622$ for filtration system). The reduction capacity is expected to be $29,710 \mathrm{~m}^{3}$ for tap water demand which could save around $\$ 8,026$ for tap water cost. It can be concluded that installing RWH system with rainwater tank capacity of $10 \mathrm{~m}^{3}$ not only provide the benefits on sustainable water resource management but also give monetary profit of $\$ 2,386$ as well.

Fig. 7 illustrated that despite the increasing of rainwater 
tank capacity which resulted in the increasing potential for tap water demand reduction, the NPV was not go in the positive direction same as the demand of the tap water reduction. According to the results in this study with specific data and conditions, rainwater tank capacity of $10-30 \mathrm{~m}^{3}$ would be preferred due to potential of the positive NPV. Therefore, three scenarios were investigated in detail to determine the best solution for water resource management through rainwater harvesting in Thailand. However, it was important to note that all three rainwater tanks capacity cannot reserve for the whole water demand in building, tap water is still required in some period of time. Throughout the service life of 40 years without RWH system, the building requires $103,149 \mathrm{~m}^{3}$ of tap water which cost about $\$ 28,605$. If the installation of RWH system with rainwater tank capacity of 30 $\mathrm{m}^{3}$ is applied, the cost of investment would be accounted for $\$ 12,092$ with the $\$ 12,564$ gained from tap water demand reduction. However, about $56,640 \mathrm{~m}^{3}$ of tap water is still necessary required which accounts for $\$ 15,707$. Therefore, the net benefit of installing RWH system with rainwater tank capacity of $30 \mathrm{~m}^{3}$ could potentially save $\$ 13,370$ in terms of economic value with the payback period of 34.8 years which could reduce $46,509 \mathrm{~m}^{3}$ of tap water resource demand as presented in Table I.

TABLE I. INFORMATION REGARDING FEASIBLE OPTIONS FOR RAINWATER HARVESTING IN THAILAND

\begin{tabular}{|c|c|c|c|c|c|c|c|c|}
\hline \multirow{2}{*}{$\begin{array}{c}\text { Tank } \\
\text { Capacity } \\
\left(\mathrm{m}^{3}\right)\end{array}$} & \multicolumn{3}{|c|}{ Water Demand } & \multicolumn{5}{|c|}{ Economic Value } \\
\hline & $\begin{array}{c}\text { Total water } \\
\text { demand } \\
\left(\mathrm{m}^{3}\right) \\
{[1]}\end{array}$ & $\begin{array}{c}\begin{array}{c}\text { RWH } \\
\text { volume } \\
\left(\mathrm{m}^{3}\right) \\
{[2]}\end{array} \\
\end{array}$ & $\begin{array}{c}\text { Tap water } \\
\text { needed } \\
\left(\mathrm{m}^{3}\right) \\
{[1]-[2]}\end{array}$ & $\begin{array}{c}\text { Investment } \\
\text { cost } \\
(\$) \\
{[3]} \\
\end{array}$ & $\begin{array}{c}\text { RWH } \\
\text { benefit } \\
(\$) \\
{[4]}\end{array}$ & $\begin{array}{c}\text { Tap water } \\
\text { needed cost } \\
(\$) \\
{[5]}\end{array}$ & $\begin{array}{c}\text { Net } \\
\text { benefit } \\
(\$) \\
\mathrm{a}-[3]+[4]-[5]\end{array}$ & $\begin{array}{c}\text { Payback } \\
\text { period } \\
\text { (years) }\end{array}$ \\
\hline 0 & 103,149 & 0 & 103,149 & 0 & 0 & $28,605^{\mathrm{a}}$ & 0 & - \\
\hline 10 & 103,149 & 29,710 & 73,439 & 5,641 & 8,026 & 20,366 & 10,625 & 16.3 \\
\hline 20 & 103,149 & 39,739 & 63,410 & 10,074 & 10,735 & 17,585 & 11,682 & 32.9 \\
\hline 30 & 103,149 & 46,509 & 56,640 & 12,092 & 12,564 & 15,707 & 13,370 & 34.8 \\
\hline
\end{tabular}

RWH systems can reduce the load of the drainage systems for Bangkok city which can prevent flooding resulted from the existing infrastructure by decreasing the peak runoff.

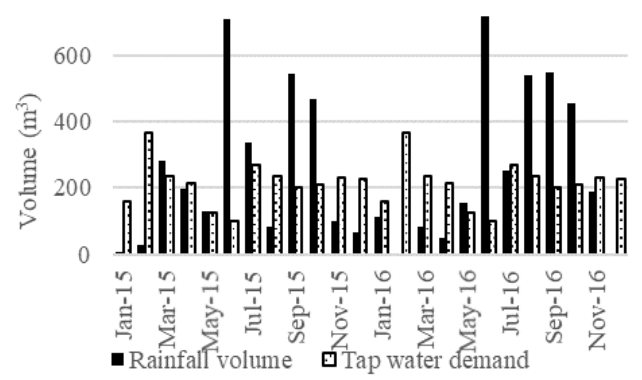

Fig. 3. Rainfall volume and tap water demand.

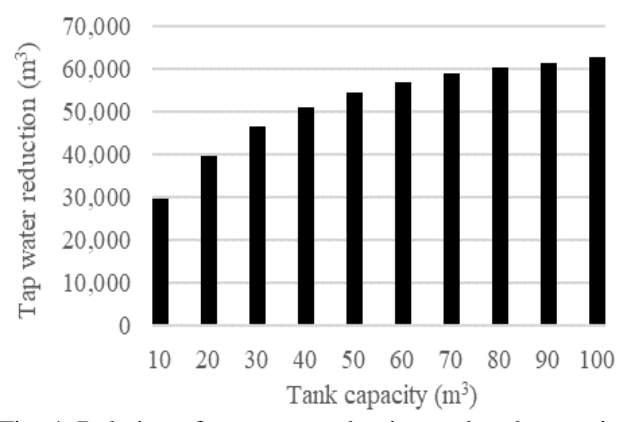

Fig. 4. Relation of tap water reduction and tank capacity.

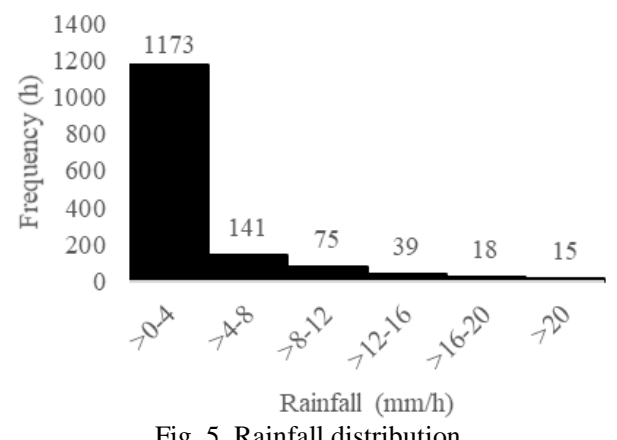

Fig. 5. Rainfall distribution

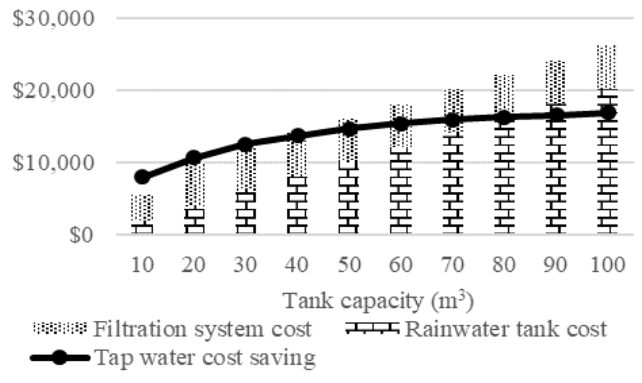

Fig. 6. Cost of RWH installation versus a saving of tap water cost.

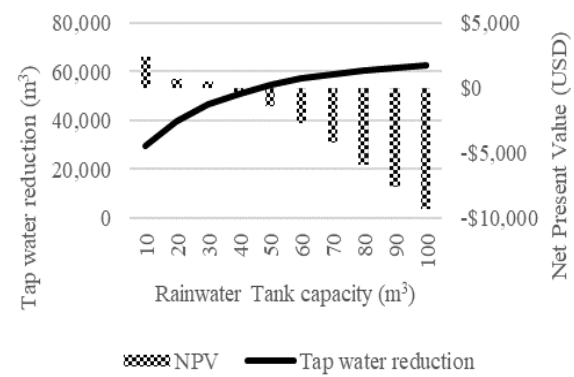

Fig. 7. NPV and tap water reduction of RWH.

If the RWH systems is installed in decent amounts, the municipalities could install smaller and less expensive storm water management systems. RWH systems can also help reducing the water resources demand from the municipal water supplies are drawn. By reducing tap water consumption, the production of water supply could potentially be reduced. As a result, the reduction in energy consumption and greenhouse gas emission from tap water production could be achieved as well as the price of water bills.

\section{CONCLUSION}

This study was aimed to make the assessment for the potential of tap water reduction and economic feasibility from 
rainwater harvesting system by utilizing the daily rainfall data in Thailand. The results can be an important tool for decision-making process for the stakeholders in designing the rainwater harvesting system. The results indicated that a small capacity of rainwater tank cannot substitute the tap water in the absence of rain for several days. In terms of economic feasibility, due to the rainwater tank cost and filtration system cost is quite high, the high capacity of tank cannot be compensated by tap water cost reduction in the specified time. Among the feasible options, the optimal tank capacity of 30 $\mathrm{m}^{3}$ was suggested in this case study due to its potential to reduce the tap water demand even the size itself cannot reserve water resource sufficiently if there is no rainfall for several consecutive days with the positive NPV. This study emphasized that the rainwater harvesting can be more economically worthwhile if the building has a higher tap water demand or the higher tap water tariff. For stormwater drainage management, if there are a lot of building that install the rainwater harvesting system, it can reduce the peak flow during heavy rains and reduce the intensity of floods in the city.

\section{REFERENCES}

[1] A. Teemusk and Ü. Mander, "Rainwater runoff quantity and quality performance from a greenroof: The effects of short-term events," Ecological Engineering, vol. 30, pp. 271-277, Jul. 2007.

[2] J. C. Berndtsson, "Green roof performance towards management of runoff water quantity and quality: A review," Ecological Engineering, vol. 36, pp. 351-360, Apr. 2010.

[3] Q. Zhang, L. Miao, X. Wang, D. Liu, L. Zhu, B. Zhou, and J. Liu, "The capacity of greening roof to reduce stormwater runoff and pollution," Landscape and Urban Planning, vol. 144, pp. 142-150, Dec. 2015.

[4] B. O. Brattebo and D. B. Booth, "Long-term stormwater quantity and quality performance of permeable pavement systems," Water Research, vol. 37, pp. 4369-4376, Nov. 2003.

[5] E. Z. Bean, W. F. Hunt, and D. A. Bidelspach, "Field survey of permeable pavement surface infiltration rates," Journal of Irrigation and Drainage Engineering, vol. 133, pp. 249-255, June. 2007.

[6] K. A. Collins, W. F. Hunt, and J. M. Hathaway, "Hydrologic comparison of four types of permeable pavement and standard asphalt in eastern North Carolina," Journal of Hydrologic Engineering, vol. 13, pp. 1146-1157, Dec. 2008.

[7] D. Leggett, R. Brown, G. Stanfield, D. Brewer, and E. Holliday, "Rainwater and greywater use in buildings: decision-making for water conservation," CIRIA report PR80, London. 2001.

[8] R. M. Roebuck, "A whole life costing approach for rainwater harvesting systems," Ph.D. dissertation, University of Bradford, Bradford, UK. 2007.

[9] A. Fewkes, "The technology, design and utility of rainwater catchment systems," pp. 27-51, 2006

[10] L. Domenech and D. Sauri, "A comparative appraisal of the use of rainwater harvesting in single and multi-family buildings of the Metropolitan Area of Barcelona (Spain): Social experience, drinking water savings and economic costs," Journal of Cleaner Production, vol. 19, pp. 598-608, Apr.-May 2011.

[11] A. Gold, R. Goo, L. Hair, and N. Arazan, "Rainwater harvesting. Policies, programs, and practices for water supply sustainability," in Proc. 2010 International Low Impact Development Conf., 2010, pp. 987-1002.
[12] L. Partzsch, "Smart regulation for water innovation - The case of decentralized rainwater technology," Journal of Cleaner Production, vol. 17, pp. 985-991, Jul. 2009.

[13] R. Siem and O. Sahin, "Energy intensity of residential rainwater tank systems: exploring the economic and environmental impacts," Journal of Cleaner Production, vol. 113, pp. 251-262, Feb. 2016.

[14] Y. D. Gómez and L. G. Teixeira, "Residential rainwater harvesting: Effects of incentive policies and water consumption over economic feasibility," Resources, Conservation and Recycling, vol. 127, pp. 56-67, Dec. 2017.

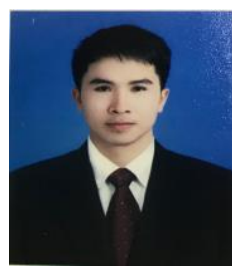

Athitinon Phupadtong is now studying the master degree in environmental engineering, Faculty of Engineering, Chulalongkorn university, Thailand. $\mathrm{He}$ completed his bachelor's degree in public health, School of Medicine, University of Phayao, Thailand 2014. His interested research is about low carbon building, environmental management, life cycle assessment and greenhouse gas mitigation.

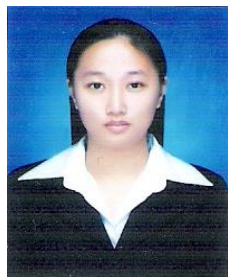

Nantamol Limphitakphong graduated the bachelor's degree in environmental Science from Faculty of Environment and Resource Studies, Mahidol university, Thailand. She then completed her master's degree in environmental engineering from Faculty of Engineering, Chulalongkorn University, Thailand She is a Ph.D candidate in environment, development and sustainability, Graduate School, Chulalongkorn

university.

She has been working in research unit of environmental management and sustainable industry as a researcher since 2010 . Her research is in a field of life cycle management, greenhouse gases emission and reduction, and low carbon city/community.

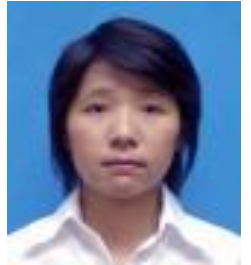

Premrudee Kanchanapiya completed her Ph.D from Graduate School of Natural Science and Technology, Division of Global Environmental Science and Engineering, Kanazawa University, Japan in 2005. She is now a researcher of the National Metal and Materials Technology Center (MTEC), National Science and Technology Development Agency (NSTDA), Thailand. Her interested research is about life cycle assessment, greenhouse gas mitigation, waste management in persistent organic pollutants (POPs) and Material flow analysis.

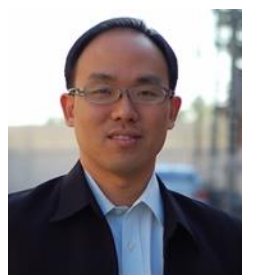

Thanapol Tantisattayakul completed his Ph.D from energy science and engineering. Faculty of Engineering, Toyoma University, Japan, in 2005 . He is an assistant professor of Faculty of Science and Technology, Thammasat University, Thailand. His interested research is about energy conservation and management, greenhouse gas mitigation, energy policy and renewable energy.

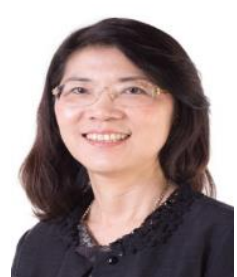

Orathai Chavalparit completed her Ph.D. from environmental science, Wageningen University, The Netherlands in 2006. She is now an associated professor of Department of Environmental Engineering, Faculty of Engineering, Chulalongkorn University, Thailand. Her interested research is about greenhouse gas management, carbon trading system and sustainable industrial management. 